University of Nebraska - Lincoln

DigitalCommons@University of Nebraska - Lincoln

$2-1-2020$

\title{
Value Added Fed and Feeder Cattle Practices: Are they Paying?
}

Elliott James Dennis

University of Nebraska - Lincoln, elliott.dennis@unl.edu

Follow this and additional works at: https://digitalcommons.unl.edu/ageconfarmmgmt

Part of the Agribusiness Commons, Beef Science Commons, Entrepreneurial and Small Business Operations Commons, Management Information Systems Commons, Other Business Commons, and the Other Economics Commons

Dennis, Elliott James, "Value Added Fed and Feeder Cattle Practices: Are they Paying?" (2020). Extension Farm and Ranch Management. 49.

https://digitalcommons.unl.edu/ageconfarmmgmt/49

This News Article is brought to you for free and open access by the Agricultural Economics Department at DigitalCommons@University of Nebraska - Lincoln. It has been accepted for inclusion in Extension Farm and Ranch Management by an authorized administrator of DigitalCommons@University of Nebraska - Lincoln. 


\section{Value Added Fed and Feeder Cattle Practices: Are they Paying? \\ Dr. Elliott Dennis, Assistant Professor, Livestock Marketing Economist, Department of Agricultural Economics, University of Nebraska - Lincoln}

This article was originally published in The Nebraska Cattleman magazine.

\section{Why we Try and Add Value to Cattle Along the Supply Chain}

A lot of time is spent on analyzing trends and movements in the quality and yield grade of slaughtered cattle and for good reason. These premiums indicate whether the market is willing to pay for producing a higher quality product. As producers respond to these premiums or discounts the relative share of quality graded cattle changes.

Premiums for fed cattle yield and quality grade, and subsequently characteristics for feeder cattle, are derived from consumer's willingness to pay for these attributes. Ultimately when consumer's buy beef products they are buying a bundle of product attributes. The most important of these attributes for U.S. consumers include taste, meat safety, nutrition, and price. Less important attributes include product novelty, fairness of markets, origin, and the environment (Tonsor, Schroeder, Lusk 2018). While consumers are extremely different and tastes and preferences for beef product attributes vary, broad classes/groups of consumers do exist that are willing to pay for higher prices for select attributes (see McKendree, Tonsor, and Wolf (2018) for details on specific consumer and cow-calf producer valuations).

Another key consideration when adding value added attributes is that U.S. domestic consumers and international consumers have different tastes and preferences. One reason why there has been so much emphasis on developing trade is because that is where beef demand is growing the fastest. Since 2010 export demand for beef has increased 100\% and outpaced the other protein products by more than $50 \%$. Compare that with domestic demand which has been relatively stable the last 10 years with minimal increases (see Tonsor Domestic and Export Demand Indices 2019). Thus raising, treating, and housing cattle in certain ways cattle to make them "export eligible" is becoming increasingly important. For example, the E.U requires hormone free beef. Other countries such as China require similar regulations. For cattle to be export eligible they need to meet certain requirements, many of which arguably have little to do with the meat quality (i.e. yield and quality grade), flavor, and tenderness.

As more producers change characteristics of cattle being offered, domestic and international demand for beef products can continue to grow. However, important consumer issues and desire for different management characteristics can change substantially year to year and each has a sizeable impact on beef demand. Thus, it is important to analyze and assess premiums being offered and how consistent these premiums have been over time in order to not over-react at the expense of loyal beef consumers. Here I review national level value added premiums paid for fed and feeder cattle.

\section{Fed Cattle Management Practices}

One way domestic and international consumer demand for value added programs shows up is in premiums paid for cattle. Packers should be willing to pay premiums for fed cattle if they believe 
they can sell boxed beef to wholesalers with an additional markup. The two value added certifications for cattle desired by packers are "All Natural" and "non hormone treated cattle (NHTC)". In August of 2016, the United States Department of Agriculture Agricultural Marketing Service (USDA-AMS) began reporting weekly average (range) weighted premiums and discounts for "All Natural" and "NHTC" cattle on a carcass basis (see LM_CT169). The NHTC premium reflects the premium for cattle that have never been treated with hormones, while the All Natural premium is applied to cattle that have never been administered hormones or antibiotics. Figure 1 plots these compared to other premiums and discounts. NHTC premiums are \$20 per cwt. and All Natural premiums are \$25 per cwt. but premiums do vary by month. All Natural cattle premiums have been increasing each month since 2018 and NHTC premiums have been either constant or increasing since 2016. For comparison, CAB premiums were roughly \$3$\$ 5$ per cwt. but constant over the past 10 years. Prime products varied substantially month to month but averaged $\$ 17$ per cwt. over the past ten years. Clearly there are large premiums for these alternative management practices relative to other beef quality grades.

\section{Feeder and Yearling Cattle Management and Practices}

Data on value added programs for feeder cattle is not readily available through USDA-AMS sale barn reporting. However, cattle that are sold via video auction generally are required to report lot level characteristics. Using data from the Western Video Market (WVM) between 2004 and 2013, Blank, Saitone, and Sexton (2016) tested different value added programs for calves and yearling cattle. Table 1 summarizes their primary findings. A wealth of information can be found in their paper on the different management practices that feeder cattle buyers are willing, and not willing, to pay for. On average, age-source verified attribute paid $1.09 \%$ more than calves without this attribute (approx. \$1.43 per cwt. more) between 2004 and 2013. However, this premium varied substantially across years. Yearlings show similar price premiums and significant variation across years. For example, yearlings that were certified as Natural yielded an average $2.72 \%$ premium between 2004 and 2013 (approx. \$2.98 per cwt. more). Feeder cattle buyers are willing to pay more for Natural yearling cattle than for Natural calves since most of the respiratory issues have already occurred and cattle are less likely to "drop out" of feedlot certified programs and into commercial lines.

\section{Summary}

Obviously, some value added management programs clearly pay more than others and some do not pay at all. However, just like with a breeding or forage management strategy where not every year the cow gets bred back or the grass has sufficient protein, a value added program strategies premiums vary year to year. Switching the way cattle are managed and raised, handled, and fed requires planning and an understanding of labor and management capabilities. Not every cattle producer could or even should switch management practices an animal health protocol - even if premiums do exist. Thus, careful planning and consideration in consultation with animal nutritionists and veterinarians before making a decision is advised. 


\section{Table and Figures}

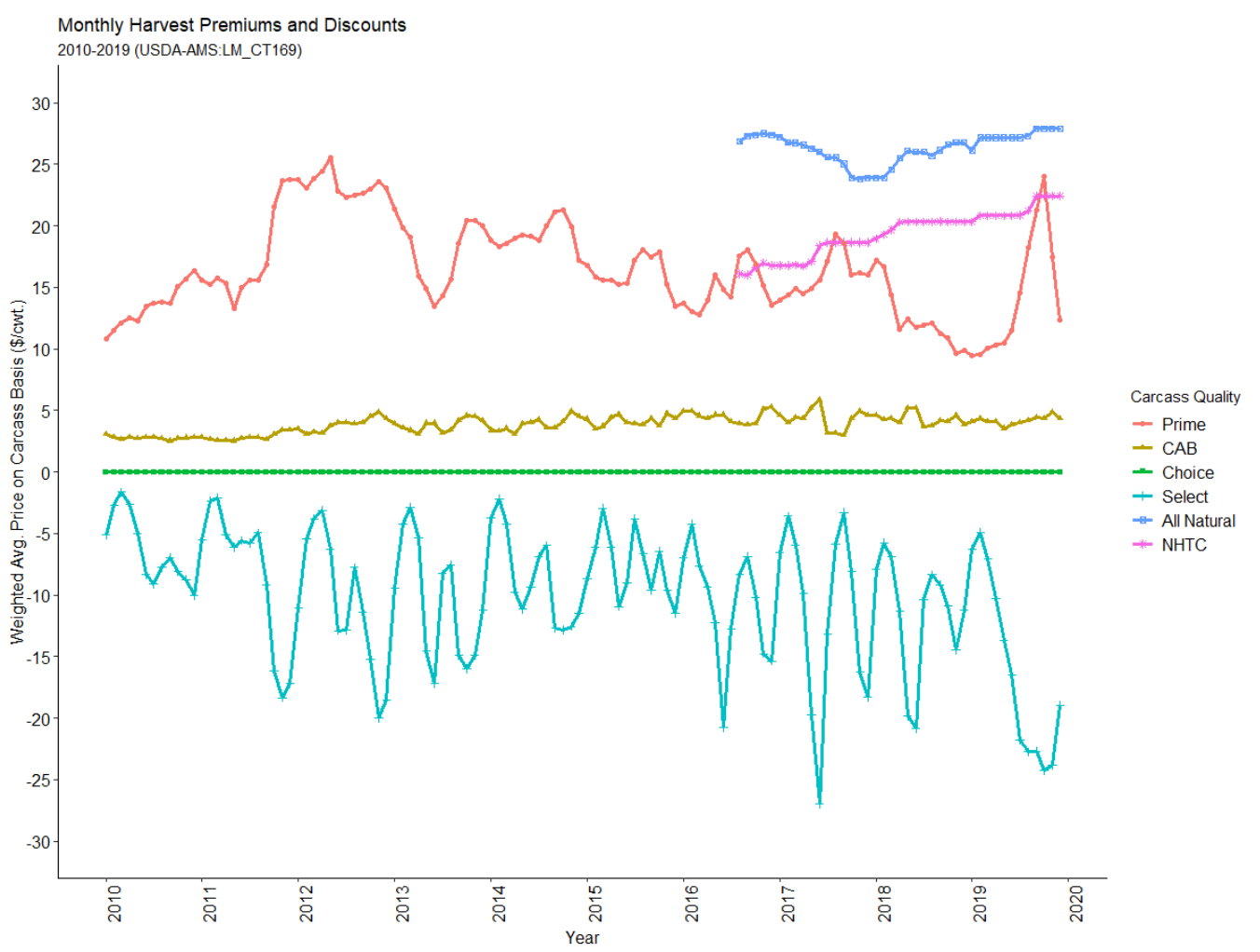

Figure 1. Historical Premiums for Cattle Carcass' in United States

Table 1. Premium as a Percentage of Sales Price

\begin{tabular}{|c|c|c|c|c|c|c|}
\hline & \multicolumn{6}{|c|}{ Calves (500-625 lbs.) } \\
\hline & '04-' 13 & $\cdot 04-65$ & '06-'07 & '08-'09 & '10-'11 & $' 12-{ }^{6} 13$ \\
\hline Preconditioned & $0.72 \%$ & $0.37 \%$ & $1.02 \%$ & $0.13 \%$ & $0.96 \%$ & $2.45 \%$ \\
\hline Age-Source Verified & $1.24 \%$ & $0.00 \%$ & $2.16 \%$ & $1.51 \%$ & $1.64 \%$ & $1.11 \%$ \\
\hline $\mathrm{CAB}$ & $1.11 \%$ & $0.99 \%$ & $1.20 \%$ & $0.83 \%$ & $0.81 \%$ & $1.39 \%$ \\
\hline Natural & $1.09 \%$ & $0.93 \%$ & $0.62 \%$ & $1.11 \%$ & $0.87 \%$ & $0.79 \%$ \\
\hline \multirow[t]{3}{*}{ Avg. Price $(\$ / \mathrm{cwt} /)$} & 130.90 & 124.87 & 122.47 & 111.43 & 138.41 & 169.16 \\
\hline & \multicolumn{6}{|c|}{ Yearlings (750-925 lbs.) } \\
\hline & '04-' 13 & '04-'05 & '06-'07 & '08-'09 & '10-'11 & $' 12-{ }^{6} 13$ \\
\hline Age-Source Verified & $0.73 \%$ & $0.00 \%$ & $0.01 \%$ & $1.01 \%$ & $0.81 \%$ & $0.49 \%$ \\
\hline CAB & $1.33 \%$ & $1.60 \%$ & $2.22 \%$ & $1.44 \%$ & $0.51 \%$ & $0.17 \%$ \\
\hline Natural & $2.72 \%$ & $4.33 \%$ & $2.72 \%$ & $1.55 \%$ & $2.64 \%$ & $2.94 \%$ \\
\hline Avg. Price (\$/cwt.) & 109.48 & 105.23 & 103.80 & 97.01 & 114.33 & 136.36 \\
\hline
\end{tabular}

Source: Blank, Steven C., Tina L. Saitone, and Richard J. Sexton (2016). "Calf and yearling prices in the western United States: Spatial, quality, and temporal factors in satellite video auctions." Journal of Agricultural and Resource Economics 41, 458-480. 